\title{
6
}

\section{Intervention in the Greek War of Independence, 1821-32}

\section{On intervention}

The intervention of Britain, Russia and France in the Greek War of Independence is regarded as the first armed intervention on humanitarian grounds in world history (as depicted by publicists from Wheaton onwards) and it took place prior to the appearance of the new concept of humanitarian intervention. As such it was pace-setting.

From the Congress of Vienna (1814-15) until the outbreak of the Greek War of Independence, there were three views on intervention at the diplomatic level.

Metternich and his close adviser Friedrich Gentz held that the great powers could take counter-revolutionary measures and intervene to suppress uprisings against legitimate rule. ${ }^{1}$ This doctrine was shared by Tsar Alexander I, and his brainchild, the Holy Alliance (Russia, Austria and Prussia), and was endorsed by the great power Congress system at the Congresses of Aix La Chapelle (November 1818) and Troppau (November 1820). ${ }^{2}$

The second view came from Britain's Foreign Secretary, Castlereagh, who stated in a famous circular (dated 19 January 1821) that states retained the right to interfere 'where their own immediate security or essential interest are seriously endangered by the internal transactions of another State' and not as 'a general and indiscriminate application to all revolutionary movements' ${ }^{3}$

The third approach was peaceful involvement, mainly mediation attempts. This can be discerned in the foreign policy initiatives of the two main rivals of Metternich on the European scene, Ioannis Capodistrias ${ }^{4}$ (co-Foreign Minister of Russia, with Nesselrode) and George Canning as British Foreign Secretary. ${ }^{5}$

A major concern (then and now) was finding the most propitious international reaction in instances of protracted internal wars. One approach was the cordon sanitaire, the sealing off of a country experiencing civil war and thus avoiding getting into a messy situation, with unpredictable results. ${ }^{6}$ But absolute noninvolvement or an arms embargo could inadvertently amount to supporting the militarily more powerful party in an internal conflict (as seen in the 1990 os with the Bosnian tragedy). To remember the famous Talleyrand adage: 'non-intervention 
est un mot diplomatique et énigmatique, qui signifie à peu près la même chose qu'intervention'?

In the nineteenth century, the concept of 'belligerency' was applicable in internal wars: another state could recognize insurgents as 'belligerents' provided the armed conflict met certain criteria, the so-called 'factual test' (protracted armed conflict, insurgents administering a large portion of a state's territory, insurgents headed by a responsible authority and so on). ${ }^{8}$ Recognition of belligerency did not imply diplomatic support for the insurgents ${ }^{9}$ but such recognition was more often than not seen as an unfriendly act by the incumbent government, as seen in the Greek-Ottoman case.

\section{The uprising and international reaction}

\section{The uprising in the making}

The spark that ignited the fuse leading to the 'Greek Revolution' (as it is called in Greece) was the French Revolution and its Enlightenment principles. ${ }^{10}$ It was then that the 'Neo-Hellenic Enlightenment' was spawned, which came to see Ottoman rule as unacceptable and the Greeks as being 'in chains', even though the educated Romioi (Orthodox Greek-speakers or Hellenized inhabitants of the Balkans) were prospering in the Ottoman Empire, with the Phanariots (their quasi-aristocracy in Constantinople) holding high state positions, despite being a subject people, the Rum millet (the Orthodox Christian community). ${ }^{11}$

The uprising was put on course with the founding in Odessa of a clandestine organization named Philiki Hetairia (Friendly Society) in September 1814, whose aim was Greek independence with Russian support. ${ }^{12}$ The Hetairia approached Capodistrias, who was influential throughout Europe (as the main opponent of Metternich's ultra-conservative European system ${ }^{13}$ ) and offered him the leadership. Capodistrias was seen as the only figure capable of steering the Greeks 'safe through the hurricane', ${ }^{14}$ given his position and friendship with Tsar Alexander I. But he declined the offer and advised against the uprising, which he regarded a folly (and duly reported the incident to the Tsar). ${ }^{15}$ The leadership of the Hetairia was then bestowed on Alexander Ypsilantis (a young Phanariot major general in the Russian army and aide-de-camp of the Tsar) in April 1820. ${ }^{16}$

At the time, the international landscape 'could hardly have been more unfavourable ${ }^{17}$ for the Greek uprising, with the Congress system and the Holy Alliance poised to subdue revolts. ${ }^{18}$ As regards a national uprising by a numerical minority, on the basis of the principle of nationalities it was 'almost unheard-of'19 and equally condemnable by the great powers. ${ }^{20}$

Given this state of affairs, Capodistrias and the most revered figure of the NeoHellenic Enlightenment, scholar Adamantios Korais (who lived in Paris), advised 
against taking up arms, and called instead for the regeneration of the Greeks through education. ${ }^{21}$ Moreover, the urge for Greek freedom was not sweeping, with the Orthodox Patriarchate, most Phanariots and many primates in the southern Balkans against it, given their privileges and affluence. ${ }^{22}$

\section{The uprising and the Ottoman and international reaction}

Despite the bad omens, Ypsilantis launched the Greek independence struggle on 21 February 1821 from Russian soil and crossed the River Prut, in the prospect of Russian assistance. In Russian army uniform, he arrived in Jassy (Moldavia) delivering a proclamation with Enlightenment rhetoric and romantic overtones, calling for a fight for the faith and the fatherland, stressing the 'natural right to freedom' and calling the Greeks to imitate the example of European peoples who had risen up in arms to foster 'freedom and happiness'. Ypsilantis referred to 'a Mighty Empire' ready to 'defend our rights', and in a letter to the Tsar wrote: 'Will you, Sire, abandon the Greeks to their fate, when a single word from you can deliver them from the most monstrous tyranny and save them of the horrors of a long and terrible struggle?'23

The Tsar ordered Ypsilantis to lay down his arms and dismissed him from the Russian army. The Orthodox Patriarch, Gregorios V, excommunicated him and issued an anathema against the Hetairia. Ypsilantis's behaviour in the principalities was a disaster, marked by 'a mixture of vanity, brutality, and incompetence.' ${ }^{24}$ ByJune, the Ottoman army quelled the ill-prepared Greek rebellion in Moldavia. ${ }^{25}$

The uprising that was to succeed was in Peloponnese from March 1821 onwards, a rugged area suited to hit-and-run warfare, with an overwhelming Christian majority, and Greek dominance in the sea due to the many ships of the nearby islands of Hydra and Spetses. Moreover, the war between the Ottomans and Ali Pasha, the powerful governor of Yannina, stranded the elite Ottoman forces, providing a unique opportunity for the Greeks to take up arms. ${ }^{26}$

The Laibach Congress was taken by surprise upon hearing of the Greek uprising. The Tsar was convinced that it had been masterminded by a sinister 'central governing committee' based in Paris. ${ }^{27}$ Metternich regarded the Ottomans and Greeks 'beyond the pale of civilization' and hoped that the rebellion would 'burn itself out'. ${ }^{28}$ Castlereagh, like France and Prussia, ${ }^{29}$ opted for strict neutrality. The Congress made sure to denounce the uprising. ${ }^{30}$

For the Ottomans, the revolt was unexpected. They were unaware that an upheaval was in the making or perhaps were 'too proud to be easily alarmed'. ${ }^{31}$ Sultan Mahmud II jumped to the conclusion that it was led by the Russians and clung to this view until the end (a self-fulfilling prophecy, as it turned out), regarding himself vindicated when Russia intervened in 1827-29. With news of massacres of Muslims, the view prevailed that the Rum were out to kill all the Muslims. Thus they were longer treated as dhimmi (protected minorities) but 
harbi (anti-Islamic warring groups) and the zimmet pact (loyalty in return for protection) ceased to apply. ${ }^{32}$

In the first months of the uprising 15,000 to 20,000 Muslims in the Peloponnese 'were murdered without mercy or remorse, ${ }^{33}$ a tragedy barely noticed in Europe. ${ }^{34}$ Mahmud, unable to punish the perpetrators, vented his fury on the Rum nearer at hand, ordering the execution of more than fifty prominent Phanariots and allowing Muslim mobs to slaughter several thousand innocent people in the capital and other cities, and to burn hundreds of churches, acts which left Europe aghast. $^{35}$

Another act of the Sultan stunned Europe even more: the hanging on the dawn of Easter Day (22 April 1821) of the octogenarian Patriarch Gregorios (and several senior bishops), held responsible for the behaviour of his flock though he was obviously innocent. The Austrian Emperor was as shocked as if the Pope had been executed. The Russian population, including the Tsar, were so incensed that a Russo-Ottoman war seemed likely. ${ }^{36}$

The Russian ambassador to the Porte, Stroganov, delivered two strongly worded protestations (drafted by Capodistrias) stating that Christians had been exterminated and demanding an end to the horrors. The Reis Effendi (foreign minister) told Stroganov that they had recriminating evidence against the Patriarch, who had been aware of the plot of the Hetairia, and that the Ottoman reaction was not meant as an all-out war against the Christians. ${ }^{37}$ Stroganov, not satisfied with the answer, left Constantinople. The British ambassador, Strangford (who was pro-Ottoman), was instructed by Castlereagh to 'bring the Porte back to reason' and to demand that the Ottoman authorities distinguish between innocent and guilty so as to restore Christian trust to the state. ${ }^{38}$

Russia, nearer to the scene and attached to its co-religionists, was in a quandary. For Alexander and the Russians, Orthodoxy and historical tradition justified coming to the support of the Greeks, as fellow Orthodox Christians. On the other hand, the Congress system and the Holy Alliance stood for the support of legitimate authority against rebels and the Tsar, for all his sympathy for the Greeks, was against their independence. ${ }^{39}$ In Russia a war party took shape and clamoured for intervention..$^{40}$ It comprised many high-ranking Russian officials, including ambassadors Stroganov, Lieven (in London) and Pozzo di Borgo (in Paris), and famous commanders from the Napoleonic wars, such as generals Kiselev, Ermolov and Diebitsch. Capodistrias was the natural leader of the war party and tried to convince the Tsar to take military steps against the Ottomans. There was also a small anti-war party, headed by Nesselrode, which feared that Greek emancipation would lead to similar calls on the part of Poles, Ukrainians and other subject peoples in Russia. ${ }^{41}$

Metternich and Castlereagh put pressure on the Tsar by addressing his worst fears. Castlereagh wrote him a personal letter, in which he acknowledged that the atrocities committed by 'the Turks' 'made humanity shudder', but that the Greeks 
were in effect Carbonari representing the spirit of insurrection and threatening the whole of Europe. ${ }^{42}$ The Tsar, finding no support for war outside Russia, concluded, in the interests of European stability, not to go to war for the Greek cause. As he put it to Capodistrias in August 1821: 'If we reply to the Turks with war ... the Paris directing committee will triumph and no government will be left standing.... At all costs we must find means to avoid war with Turkey. ${ }^{43}$ Capodistrias did his best to make him change his mind and went as far as suggesting the expulsion of the Ottomans from the Danubian principalities. ${ }^{44}$ Realizing that Alexander was unflinching, he left the Russian service a year later (August 1822), though his resignation was not accepted (he went on indefinite leave and settled in Geneva). ${ }^{45}$

In the latter part of 1821 and first part of 1822 , two appalling events took place within seven months. The first was the conquest of Tripolis (5-6 October 1821) by the Greeks, amidst carnage that defies description, with the indiscriminate massacring of 8 , 000 to 15,000 unarmed people of all ages. It was then that many philhellenes left the region in disgust, including Colonel Thomas Gordon (the later historian of the Greek uprising). News of this horrifying deed trickled abroad but there was no condemnation. The standard line was that the exaggerated Greek reaction was due to the centuries-old 'Turkish yoke'. ${ }^{46}$

The European response was very different in April 1822 when the Ottomans laid waste the affluent island of Chios. Gordon likened it to the carnage of Tripolis, with 'the victors butchering indiscriminately all who came in their way. ${ }^{47}$ According to Strangford, Ottoman ferocity had been carried 'to a pitch which makes humanity shudder'. ${ }^{48}$ Some 25 ,000 were killed and 45,000 enslaved. The European uproar was even greater than in 1821. Delacroix painted Scenes of the Massacre of Chios, causing a sensation when it was unveiled in Paris. ${ }^{49}$

Castlereagh instructed Strangford to tell the Porte that 'a repetition of such deeds of blood' and 'ferocious and hateful barbarism' would not be tolerated and would lead to the withdrawal of diplomatic missions. ${ }^{50}$ The British ambassador lectured Sadiq-Effendi (the Reis Effendi) about 'the duties of humanity which existed in all civilized countries', which 'obliged the Powers not to remain indifferent observers of the atrocities of this war, of the only war in the entire world' ${ }^{51}$ Sadiq-Effendi stated that events in Chios had 'deeply pained the Sultan' but that the Chiots had started it all by massacring Muslims, adding pointedly that reference had never been made to the massacres of Muslims in Tripolis, Navarino, Corinth and Athens. ${ }^{52}$

\section{The philhellenes}

Contrary to the aloofness of the powers, bar Russia, European and American public opinion had been on the Greek side almost from the beginning. What made the difference with the uprising of the Serbs in previous decades and the more recent rebellions for political rights in Spain, Portugal, Naples, Sicily, Piedmont 
and Sardinia (1820-21) was that the Greek uprising had become a cause célèbre, giving rise to an impressive wave of what came to be known as 'philhellenism'. Greek committees sprung up in various parts of Europe and the US, starting with Spain and Switzerland, concluding with the London Greek Committee (1823) and the Paris Greek Committee (1825), all of which were engaged in fund-raising, writing pamphlets, securing funds, foodstuffs, medicine, arms and ammunition, as well as paying ransom to free enslaved Greeks (a Russian prerogative). Over a thousand 'philhellenes', Italians, French, English, Scots, Irish, Germans, Swiss, Poles, Scandinavians, Americans, Spaniards, Portuguese, Dutch, Hungarians and others (but not Russians, much to Capodistrias's chagrin ${ }^{53}$ ) came to assist the Greeks in their struggle, including a unique celebrity, Lord Byron, with some of his greatest romantic poems referring to the Greek cause (Childe Harold, Don Juan and others). ${ }^{54}$

The philhellenes were convinced of the righteousness of the Greek cause and of the barbarity of the 'Turks'. Thus the atrocities and other barbarous acts committed by the Greeks - the few that were reported - were wished away and had little impact in stemming the enthusiasm. There was strong public pressure from elite circles in Britain (apart from Byron, Shelley, Bentham, Ricardo, Lord Erskine, Lord Russell and others), Russia (a string of poets, including Pushkin), France (Chateaubriand, Hugo, Constant, Delacroix, Berlioz, Villemain, Firmin Didot), Switzerland (banker-philanthropist Eynard) and the US (Hellenist Professor Everett, three ex-Presidents, Jefferson, Adams and Madison, and future President Harrison) to assist the beleaguered Greeks. Ludwig I of Bavaria and US President Monroe contemplated recognition of statehood (Madison suggested reference to the Greek cause in the Monroe Doctrine of December 1823) but Secretary of State (and future President) John Quincy Adams, a pragmatist, put an end to any such ventures. ${ }^{55}$

European and American identification with the Greeks was also due to the fact that they were regarded as the descendants of the ancient Greeks (with ancient Greece regarded as 'the cradle of European civilization'). Shelley's words in the preface of his poem Hellas captured the overall mood: 'We are all Greeks. Our laws, our literature, our religion [sic], our art have their roots in Greece. But for Greece ... we might still have been savages and idolators... The Modern Greek is the descendant of those glorious beings. ${ }^{56}$ It was a great advantage to the Greek cause that Europe and America were then under the spell of classicism, which venerated the ancient Greeks, as well as romanticism, making the uprising appear a most romantic episode. ${ }^{57}$

For the Russians, the Greeks striving for freedom were the descendants of the venerated Byzantines (to whom they owed Christianity, the alphabet and iconography) as well as the ancient Greeks. Co-religionism brought the support of the Russian Church and wide public support, even in rural areas, among the illiterate strata and peasants, something unique in Europe in those days. Furthermore, 
Greeks were very much present in Russia as prosperous merchants, educators and high-ranking civil servants, diplomats, military personnel and members of the aristocracy, several of them close to the Tsar and court, a case in point being Capodistrias, senior officials Sturdza and Destounis and the Ypsilantis family. ${ }^{58}$

There is also an intriguing dimension to the Russian-Greek link, little known outside a small circle of Soviet and Russian researchers: the impact it had and the interplay it created between the Greek would-be insurgents in Moldavia (in February-March 1821) and the Russian would-be Decembrists (in December 1825). ${ }^{59}$ This characteristic example of 'entangled histories' can be seen in: (1) the contacts between Ypsilantis and other aristocratic officers of the Russian army (most of them liberals and future Decembrists) in various salons and Masonic lodges, where they discussed and planned their respective uprisings (the liberation of the Greeks and the liberation of Russia from absolutism); (2) the assistance given by individual officers (most of them future Decembrists) to Ypsilantis in his Danubian endeavour, without the approval of the central government or army; and (3) the impact Ypsilantis's uprising had in Russia, among the future Decembrists, officers and lay people, including more than a dozen philhellene poets. Ironically for them, as in the case of Alexander's conspiracy theory (the 'Paris committee'), the Greek uprising would provide the spark, together with the uprisings in the Italian and Iberian peninsulas, for a wider European conflagration, which would overthrow absolutist rule, including absolutism in Russia. ${ }^{60}$

\section{3-25: Canning, Russia, Byron, Ibrahim and barbarization}

\section{Canning, Russia, Byron}

When Canning succeeded Castlereagh (following his suicide) in September 1822 he followed his predecessor's neutral policy. Canning had 'no regard for the Turks as such, but he did not mean to excite the millions of Mohammedans in India by a display of partiality' ${ }^{61}$ and 'did not share the illusions of the Philhellenes about the modern Greeks', ${ }^{62}$ regarding them 'a most rascally set'. ${ }^{63} \mathrm{He}$ stood for the maintenance of the Ottoman Empire and 'he held that, if war occurred, Russia would gobble Greece at one mouthful and Turkey at the next'. ${ }^{64}$ Yet, having in the meantime become renowned as the defender of oppressed peoples in Latin America and Europe, he came to regard the Greek cause more favourably, vindicating those Greeks who from the start regarded him as a philhellene. ${ }^{65}$

The goals of Canning's Greek policy from 1824 can be summarized as follows: (1) to further British interests in the region; (2) not to allow Russia to take undue advantage of the Greek case; (3) to limit French influence and not to permit a Franco-Russian alliance; ${ }^{66}(4)$ not to permit the collapse of the Ottoman Empire; and (5) to bring about an autonomous or independent Greece leaning towards Britain. ${ }^{67}$ 
Canning recognized the Greeks as belligerents in March 1823. The act as such was not pro-Greek but aimed to protect British commerce from piracy and to hold the Greeks accountable for such actions. ${ }^{6}$ Sadiq-Effendi did not miss the opportunity to ask Strangford whether Canning was now prepared to 'allow the right of America to recognise Irish rebels as belligerents' ${ }^{69}$ When Metternich complained, Canning's reaction was that the Greeks had acquired 'a certain degree of force and consistency' and 'monstrous consequences' would follow from treating them as pirates, adding '[c]an it be necessary to suggest the advantage to humanity of bringing within the regulated limits of civilised war, a contest which was marked on its outset on both sides, with disgusting barbarities? ${ }^{70}$

The Greeks, in spite of their poor organization and vicious infighting, were able to hold their own even after the Ottomans had quelled Ali Pasha in Yannina and had sent abundant forces to the south. Thus, in January 1824 the Sultan took 'a bold but desperate step" ${ }^{71}$ and summoned the semi-independent Muhammad Ali Pasha, the governor of Egypt, to subdue the Greeks. He agreed to send his son, Ibrahim Pasha, as head of an army and navy. The move, though successful militarily, was to prove a grave mistake.

In the same month (January 1824), Russia took the initiative with a mémoire proposing the establishment of three autonomous Greek principalities. The proposal was discussed in two conferences at St Petersburg (June 1824-March 1825). Britain chose not to participate, hoping that the Russian proposal would not fly. The Russian scheme fell short of the Greek demand for independence but provided more territory than the Greeks would have been able to secure though their own efforts. ${ }^{72}$

The Porte did not accept the Russian proposal and Mavrokordatos (the Anglophile acting as Greek Foreign Minister) sent a letter to Canning rejecting it and appealing for British support. Canning replied (in December 1824) reiterating British neutrality but hinted that Britain might mediate in the future and would not be party to an agreement unacceptable to the Greeks. ${ }^{73}$

Meanwhile, a unique event was to create a sensation, reviving the waning international public interest in the Greek cause. Byron, the idol of literary Europe and America, had arrived in Messolonghi in January 1824, inspiring romantic Byronists across Europe to join him. The Porte had asked Canning to shelve Byron's arrival but he had turned a deaf ear. ${ }^{74}$ After a perilous journey by ship from the Ionian Islands, Byron, in scarlet military uniform, set foot in Messolonghi to a hero's welcome by an enthusiastic crowd and was made head of the Greek and philhellene army in western Greece, known as the Byron Brigade. His motley brigade saw no military action but his mere presence 'electrified' the Greeks ${ }^{75}$ and acted as a 'talisman'76 internationally. Byron, while in Messolonghi, displayed practical spirit and assisted the Greek cause both financially and organizationally. The Byron magic was to reach its apogee a hundred days later when he 'died immortally'77 from illness (19 April 1824). His death assured the Greek cause 
thereafter of constant European concern, which was much needed in view of the arrival of Ibrahim and his forces early the next year. ${ }^{78}$

\section{Ibrahim and the barbarization rumour}

Ibrahim landed in the Peloponnese on 24 February 1825 and embarked upon a campaign of conquest and devastation (though initially he refrained from indiscriminate killings ${ }^{79}$ ) with the Greeks no match for his military acumen and small but well disciplined army. ${ }^{80}$ By the end of the year there were only some pockets of resistance left. Only great power intervention could save the Greeks. Indeed, they 'were to be rescued, though in an unplanned and even reluctant way, by the great powers' ${ }^{81}$

The Greeks, in desperation, placed themselves in 1825, by an 'Act of Submission', under the protection in turn of Britain, France and Russia, none of which accepted it. A Greek delegation met Canning (29 September 1825), who dismissed the protectorate idea but said that 'there might be a point in the contest when Great Britain would promote a fair and safe compromise'.82 The Greek deputies' reaction was 'independence or death'. ${ }^{83}$

The idea of British mediation matured in the mind of Canning, preferably Britain on its own but if that proved impossible then together with Russia. He sent his cousin, Stratford Canning, to be the new ambassador to Constantinople, ${ }^{84}$ with instructions to convince the Porte of the need for British mediation. ${ }^{85}$

At this juncture an ugly hearsay gave rise to a sense of urgency: that Ibrahim intended to depopulate the Peloponnese and re-people it with Muslims. ${ }^{86}$ The Russian ambassador in London, Christopher Lieven, and his formidable wife, Dorothea Lieven, told Canning at a meeting in Seaford (25 October 1825) that the 'Court of Russia, had positive information that ... an agreement was entered into by the Porte with the Pasha of Egypt ... to remove the whole Greek population, carrying them off into slavery in Egypt or elsewhere, and to re-people the country with Egyptians and others of the Mohammedan religion'. ${ }^{87}$

The 'barbarization project' was almost certainly smoke without a fire but it was crucial in spurring eventual military intervention. Canning could hardly treat such a monstrosity lightly. As he put it, 'supposing the fact to be true' it would not be possible 'to justify to the country a continued abstinence from interposition'. ${ }^{88}$ According to Granville Stapleton, Canning's secretary and confidant, it was then that he opted for the use of force if necessary to prevent the consummation of this atrocious design'. 89

Canning asked Stratford to see whether there was truth in the rumour and 'to declare in the most distinct terms to the Porte that Great Britain would not permit the execution of a system of depopulation'. ${ }^{90}$ The British admiral in the Mediterranean was instructed to meet Ibrahim and to demand 'an explicit disavowal ... or a formal renunciation of it, if ever entertained'. ${ }^{1}$ Otherwise 
'effectual means will be taken' by the British navy to prevent 'the accomplishment of so unwarrantable a project'. ${ }^{92}$ Ibrahim denied any such design ${ }^{93}$ and so did the Reis-Effendi, who referred to it to Stratford as 'imbecility'. ${ }^{94}$ But the pro-Greek Stratford wrote to the Foreign Office to say that Ibrahim 'acted on a system little short of extermination ... and there was room to apprehend that many of his prisoners had been sent into Egypt as slaves, the children, it was asserted, being made to embrace the Mahommedan Faith'.95

\section{International agreements in St Petersburg and London}

\section{The St Petersburg Protocol and its aftermath}

In the last months of 1825 Alexander contemplated war to save the Greeks. ${ }^{96}$ But he died unexpectedly (in December 1825) and was succeeded by his younger brother, Nicholas I, who took over in the midst of the Decembrist revolt.

The new Tsar tried to use the Greek question to Russia's advantage and, if need be, he intended to act alone, even though he despised the Greeks as rebels against legitimate authority. ${ }^{97}$ Under the circumstances, Canning decided to act quickly, jointly with Russia. ${ }^{98}$ He persuaded the Duke of Wellington to undertake a delicate mission to St Petersburg with two objectives: to avert a war by smoothing Russo-Ottoman differences; and to arrive at a common line of action on the Greek question. Ibrahim's atrocities and the barbarization project were to be the justification for their common action. ${ }^{99}$

Wellington succeeded in his second task (the Greek question) but not in the first. Nicholas appeared to be on a war footing in relation to the Ottoman Empire and unconcerned with the Greek question. But agreement began to take shape when Lieven arrived and acted as the main protagonist on the Russian side. The final text was ready and signed on 4 April 1826 by Wellington and by both Nesselrode and Lieven. ${ }^{100}$

The St Petersburg Protocol offered mediation to the Porte, which, if accepted, would to lead to an autonomous Greece tributary to the Sultan. If the Porte did not agree, mediation and autonomy were to remain on the table. A self-denying clause was included, renouncing any 'augmentation of territory, any exclusive influence' or commercial advantage. There was also mention of 'intervention whether jointly or separately between the Porte and the Greeks', a Russian clause, if mediation failed. ${ }^{101}$

In the meantime, Messolonghi fell to the Egyptians and Ottomans. The conquest of a town famous due to Byron created a stir across Europe, with an array of poems, musical plays, essays and sermons. Victor Hugo wrote a macabre poem, 'The Seraglio Heads', in which Ibrahim is presented as sending to the Sultan 6,0oo severed heads. Delacroix painted his famous Grèce sur les ruines de Missolonghi, and the next year the Paris Salon exhibited twenty-one paintings 
with Greek themes. Ibrahim may have conquered the town, but Messolonghi had become a symbol for European public opinion, and more pressure was put on governments to rescue the Greeks. ${ }^{102}$

Messolonghi's impact was great in France, which until then had followed an equivocal policy. Despite sympathy among the educated public for the Greeks, the French government had followed a policy of neutrality but in fact provided assistance to Egypt, with which links had existed for decades (French officers and advisers had modernized Egypt's army and navy). France, through Egypt, was influential in the Levant at the expense of Britain and Russia.

In 1825 the French philhellenic spirit became intense, bringing together the various bitter divisions of Restoration France: Liberals, Bonapartists as well as ultra-Royalists and Royalists, such as Chateaubriand, the ex-Foreign Minister. The conservatives were mainly motivated by the suffering of Christians, the liberals by the call for national liberation. Chateaubriand, in his influential Note en Grèce (1825), urged the French King and other monarchs: 'Will our century watch hordes of savages extinguish civilization at its rebirth on the tomb of a people who civilized the world? Will Christendom calmly allow Turks to strangle Christians?' ${ }^{103}$ In the Comité grec de Paris, set up in 1825, one sees major figures apart from Chateaubriand and men of arts and letters: Lafayette, the dukes de Broglie, de Dalberg, de Laborde and other members of the higher French aristocracy, generals Sébastiani (Foreign Minister 1830-32), Gérard, Mathieu and Dumas, and bankers and industrialists Laffitte, Ternaux and Casimir-Périer. Eventually France withdrew its assistance to the Egyptians and remained neutral until the end of 1827 . More generally the Greek case, as previously with the Spanish crisis of 1823, provided the opportunity for France to re-enter the scene as a great power. ${ }^{104}$

Ibrahim had almost total control of the Peloponnese and of the north of the Gulf of Corinth, having captured Athens after a long siege. But the Greeks remained dominant in the sea now with the assistance of the legendary Lord Cochrane, the ex-British officer Captain Hastings with the Karteria (one of the first steamships to engage in combat), Captain Hamilton with the British warship the Cambrian and the French Rear Admiral de Rigny, who supported the Greeks to the extent permitted by France's neutrality. Soon the British Vice Admiral Codrington was to arrive on the scene, whose role was to prove decisive. ${ }^{105}$

Ambassadors Stratford and Ribeaupierre (Russia) put pressure on the new Ottoman Foreign Minister, Pertev-Effendi (a hard-liner who had replaced moderate Saida-Effendi in March $1826^{106}$ ), to accept the mediation offered by the Protocol. Pertev-Effendi rejected it, adding that it was unacceptable on Muslim religious grounds as well. ${ }^{107}$

Canning proposed to the Tsar common action: 'to seize the first occasion of recognizing as an independent State such portion of her [Greece's] territory as should have freed itself from Turkish dominion', ${ }^{108}$ but that was too radical for 
Nicholas to accept. ${ }^{109}$ The pressure on the Porte produced the Convention of Akkermann (October 1826), with the Porte giving in to various Russian demands unrelated to the Greek question. ${ }^{110}$

\section{The Treaty of London}

Meanwhile, efforts were being made to convince the other three powers to accede to the Protocol but only France (King Charles X, Premier de Villèle) agreed to join, and then only provided the Protocol was turned into a treaty. ${ }^{111}$ Canning (who had been privately in Paris for weeks to lobby the French) readily accepted and so did Lieven. Wellington was decidedly against this course of action, however. ${ }^{112}$ Canning wrote to Lieven to say 'a contest so ferocious ... so intolerable to civilized Europe, justifies extraordinary intervention, and renders lawful any expedients short of positive hostility.' ${ }^{113}$

The negotiations started with France tabling the first draft of the Treaty, which did not include means of enforcement (January 1827). A Russian draft (March) envisaged a naval blockade if the Porte was unyielding and it implied the use of armed force. British Prime Minister Liverpool was taken ill with paralysis; after a brief tussle between Wellington and Canning, the latter become Prime Minister. On 6 July 1827 the Treaty of London was signed, after six months of acrimonious deliberations between Dudley, the new British Foreign Secretary, Lieven and Polignac (the French ambassador in London). The Treaty followed the lines of the Protocol. ${ }^{114}$

The official justification of the Treaty was stated in the preamble: 'putting an end to the sanguinary struggle' which has led to 'the disorders of anarchy'; 'fresh impediments to the commerce of the States of Europe and gives opportunity for acts of Piracy'; 'putting a stop to the effusion of blood'; 're-establish peace between the contending parties by means of an arrangement called for, no less by sentiments of humanity, than by interests for the tranquillity of Europe'.115 Although stopping the effusion of blood was not the only justification, it is probably the first time in history that such concern was invoked expressis verbis as 'a justification for intervention'. ${ }^{116}$

The Treaty offered three-power mediation, called for an immediate armistice and provided for the creation of Greece as 'a dependency of Turkey'. If one of the contending parties or both declined, the powers 'will, nevertheless, continue to pursue the work of pacification. ${ }^{.17}$

The Treaty included a secret clause (leaked to The Times) to the effect that the three powers 'will jointly exert all their efforts to accomplish the object of such armistice, without, however, taking any part in the hostilities between the two contending parties'. ${ }^{\prime 18}$ In the text, the various instructions to the three admirals boiled down to the following: if the Ottomans refused an armistice, they were to 'observe extreme care to prevent the measures which you shall adopt against the 
Ottoman marine from degenerating into hostilities' and 'not to make use of that force unless the Turks persist in forcing the passages which they [the admirals] have intercepted'. ${ }^{119}$

How could the admirals accomplish their task without hostilities? According to Marriott, '[e]ither the matter had not been clearly thought out, or there was a deliberate intention to leave the Gordian knot to be cut by the Executive Officers of the Powers', that is, the three admirals in the Levant. ${ }^{120}$ As wryly put by Woodhouse: 'This directive [to the admirals], covering all contingencies and none, bears the stigmata of official drafting by men who had shut their eyes to facts and hoped for the best. It shifted all ill-defined responsibility to the Admirals, and left to them the glory and the blame'. ${ }^{121}$ The lack of clarity is probably due to the fact that the Treaty was 'a compromise between a strictly impartial mediation and an open intervention on behalf of the Greeks'. ${ }^{122}$

The Realpolitik reasons for the Treaty were for France to keep Britain and Russia in check; Britain to restrain Russia from going to war and gaining advantage from the situation; and Russia to avail itself of the opportunity to gain advantages. As Crawley has put it, 'the mutual suspicion of the Powers was the Greeks' best security: no one of them was concerned to make Greece an independent State (Canning himself gave no clear indication of it) but each was driven in that direction by the fear of allowing the other an excuse for further interference'. ${ }^{123}$

By July 1827, when the Treaty was signed, 'the war was as good as won' by the Ottomans and Egyptians, but, as Turkish scholars have argued, the victory 'was snatched out' of their hands. ${ }^{124}$

The Greeks wisely accepted the armistice and mediation, though in practice they did not adhere to the armistice, with the justification that Ibrahim continued to ravage the country. ${ }^{125}$ The provisional Greek government nominated two Britons to head the Greek forces: Cochrane the navy, and ex-general Church the army. Cochrane and Church, together with Blanquière and Hamilton, were instrumental in convincing the rival Greeks factions (and even the proBritish Mavrokordatos) that the wisest option was to nominate Capodistrias as President. $^{126}$

The ambassadors of the three powers, Stratford, Ribeaupierre and Guilleminot (France), tried to convince Foreign Minister Pertev-Effendi to accept a cease-fire and mediation, and on 12 August 1827 gave only fourteen days to the Porte to come up with an answer. On the fourteenth day the reaction of the Porte was negative. The ambassadors sent a verbal note to Pertev-Effendi making it clear that their governments intended to implement the armistice even without the approval of the Porte, but nothing came of this. ${ }^{127}$

Metternich, realizing that the Ottomans were in a quandary, offered mediation to save them, which was enthusiastically accepted by the Divan (Ottoman cabinet) and the Sultan, on 23 October 1827. But unfortunately for the Ottomans, the Battle of Navarino had taken place a few days earlier. ${ }^{128}$ 


\section{Navarino and the years $1828-32$}

\section{Navarino and its aftermath}

Let us see what had transpired. Following the Porte's rejection, the admirals were instructed by the Constantinople ambassadors to enforce the armistice. ${ }^{129}$ The immediate concern of the admirals was to use their ships effectively to prevent the arrival of fresh Egyptian troops and supplies, and to do so without provoking hostilities. ${ }^{130}$ Codrington asked Stratford for clarification, whose reply ( 1 September) was that 'the prevention of supplies is ultimately to be enforced, if necessary, and when all other means are exhausted, by cannon shot'. ${ }^{131}$

Codrington and de Rigny met Ibrahim at Navarino (on 25 September 1827) and he seemed forthcoming regarding an armistice ${ }^{132}$ but he continued his devastating campaign against the Greeks by land, which was now even more destructive than before. ${ }^{133}$ Following the arrival of the Russian squadron under Rear Admiral Heiden, the three admirals agreed to enter the bay 'without effusion of blood and without hostilities, but simply by the imposing presence of the squadrons', as the only way to fulfil their mandate, enforce an armistice and halt Ibrahim's onslaught. ${ }^{134}$

The three squadrons (first the British, followed by the French and Russian) entered Navarino on 20 October 1827 , outnumbered by 1,298 to 2,000 Ottoman guns and with half the number of ships of the Egyptian and Ottoman fleets. The first shot was fired by their opponents, apparently without instructions. The outcome is well known: the annihilation of the Egyptian and Ottoman fleets. ${ }^{135}$ Navarino, the last major naval battle fought under sail, in eighteenth-century battle conditions, has passed into legend, not least in the lore of humanitarian intervention. Navarino is retrospectively regarded as the first instance of use of force for humanitarian purposes as we understand it today, ${ }^{136}$ but a sound case could be made that its humanitarian rationale is unconvincing. ${ }^{137}$ Retrospective or not, convincing or not, as early as the end of the 1820 s the intervention of Navarino was labelled ' $d$ ' humanité' in several official documents. ${ }^{138}$

Undoubtedly the battle had come about 'by accident rather than design'139 but it 'strengthened enormously the position of the Greeks'. ${ }^{140}$ In fact the battle itself brought no immediate relief to the Greeks: Ibrahim remained entrenched in the Peloponnese for more than a year. The real effect of Navarino in delivering the Greeks took time to materialize, but one thing is certain: it made it almost impossible for the three powers to change track, even if they wanted to, as did Britain under Wellington. ${ }^{141}$

The news of the battle was received with amazement in Europe. The French public were delighted, though not the government, the Russians were jubilant, the Austrians appalled and the British uneasy. The Ottomans called it a 'revolting outrage' and denounced the Convention of Akkermann. ${ }^{142}$ For Metternich it was a 'frightful catastrophe'. ${ }^{143}$ Foreign Secretary Dudley addressed ten queries 
to Codrington regarding the battle and whether he had followed instructions, to which the admiral answered point by point. ${ }^{144}$ When Wellington formed his government in January 1828, the speech from the throne (which he had drafted) used the famous words 'untoward event'. ${ }^{145}$ The speech was greeted with uproar in both Houses, with most speakers praising Codrington. Wellington tried to explain away the phrase by claiming he meant 'unexpected' or 'unfortunate.' ${ }^{146}$

The Ottoman government demanded condemnation of the 'tragic episode' as unintended, compensation and the three powers to allow the Porte to treat the matter for what it was, an internal affair. The three ambassadors replied that the battle had indeed been unintended but the Ottomans had first opened fire; their states desired friendly relations with the Porte, provided there was an armistice and mediation; and the London Treaty was aimed at European peace and was to the benefit of the Ottoman Empire. ${ }^{147}$

Pertev-Effendi's reaction was that only the submission of the Rum would resolve the question; upon their submission they would be pardoned, despite their crimes of treason and rebellion. 'Greece', he asserted, does not exist, the Rum are simply a millet headed by their patriarch. When Guilleminot questioned whether one can speak of submission after such a long struggle, Pertev-Effendi retorted that 'it is well known what has kept the rebellion alive', implying foreign encouragement. ${ }^{148}$

Mahmud for his part made the following concessions (as he saw them): he would drop his demand for the rebels to pay compensation for the costs of the war, and, after their submission, he would relieve them of paying capital taxes for a year. The ambassadors made a last-ditch attempt at compromise, calling for abandonment of warfare and the acceptance of the autonomy status of the Greeks as provided by the London Treaty, but the Divan remained adamant and the three ambassadors left the Ottoman capital (December 1827). ${ }^{149}$

\section{Events of 1828-32}

By the end of 1827 the fate of Greece was sealed, or so it seems with the benefit of hindsight, in view of the intrusive London Treaty, Navarino, Ottoman intransigence, Russia's willingness to go to war, unremitting pressure from France on its two allies to allow France to send an expeditionary force to expel Ibrahim, and Capodistrias in charge, with his great diplomatic skills and international links. Only two things remained unresolved: whether Greece was to be autonomous or independent, and its geographical limits. Yet it took three more gruelling years to make the Greek dream and the Ottoman nightmare a reality. If one absence was deeply felt in the Greek camp it was that of Canning, especially from the moment Wellington took over.

Indeed, the Iron Duke did his best to undo the consequences of the London Treaty and Navarino. His hostility was based on his conviction that Greece was 
destined to become a maritime state and from this he mistakenly surmised that the new state was bound to be antagonistic towards Britain and to become 'a Russian dependency'. ${ }^{150}$ His fear of Russia made Britain openly pro-Ottoman and this encouraged the Sultan to remain defiant. ${ }^{151}$ Thus all the dividends of years of incremental diplomacy by Canning were thrown overboard and thereafter Britain played second fiddle to Russia and France in the Greek affair. ${ }^{152}$

With Russia and France standing firm, the Sultan opted for war with Russia instead of accepting the inevitable, namely Greek autonomy. Had Mahmud acted with restraint and bent with the wind after Navarino - even though Navarino was admittedly 'rather provoking'153 - the Ottomans would have avoided an unwinnable war with Russia. Actually, moderation had been advised in a memorandum to the Sultan from a group of senior officials, headed by the eminent poet Izzet Mollâ and Hamid Bey (a former Reis-Effendi). The reasoning of the peace lobby was countered by the war lobby under Pertev-Effendi, which advocated intransigence in a memorandum that was endorsed by the Sultan. ${ }^{154}$

Metternich, in a last attempt to avoid a war that was bound to go Russia's way, proposed (15 March 1828) to 'invite the Porte to recognise the autonomy of Peloponnese and Islands only' and on refusal 'to recognise their entire independence.' ${ }^{155}$ The Tsar was indignant with this Austrian proposal. As he put it, 'I detest, I abhor the Greeks, I consider them as revolted subjects and I do not desire their independence; Austria has abandoned her principles'. ${ }^{156}$

Meanwhile, France was able to obtain Wellington's reluctant consent for the sending of a French expeditionary force in the name of the three allies. The force of some 14,000 under General Nicolas Maison arrived in the Peloponnese in September 1828. Maison's mission, to expel Ibrahim's forces, was achieved almost without firing a shot, with only some mock sieges and momentary resistance in only two cases. ${ }^{157}$

The reconvened London Conference instructed the three former ambassadors to the Porte to suggest frontiers for Greece and an ambassadors' conference was convened on the island of Poros (September-December 1828), urged along by President Capodistrias. The ambassadors' report (12 December 1828) recommended the frontier run from the Gulf of Volos (in the east) to the Gulf of Arta (in the west), incorporating the large island of Euboea. The faraway islands of Samos and Crete were also suggested for inclusion. The report was not accepted as such but instead as a basis for negotiations (22 March 1829), with Samos and Crete not included. Stratford resigned his embassy in disgust. ${ }^{158}$

The Russo-Ottoman war which had started in April 1828 raged on much longer than had been anticipated, due to stiff resistance by the Ottomans. When the victorious Russian army entered Adrianople in August 1829 a committee under the head of the Russian Council of Ministers reached the conclusion that 'the advantages of the preservation of the Ottoman Empire outweigh its disadvantages', but if the Empire collapsed in the future Russia must take 'the most 
energetic measures to ensure that the exit from the Black Sea is not seized by any other power whatsoever. ${ }^{159}$ The committee also considered but did not adopt a previous plan by Capodistrias for the creation of a Balkan confederation of five independent states (Dacia, Serbia, Macedonia, Epirus and Greece). ${ }^{160}$

The Treaty of Adrianople (14 September 1829) made the Porte accept an autonomous Greece. This time it was the turn of Capodistrias to reject the tributary status. Now Metternich and Wellington opted for an independent Greece, for they feared that Russian influence would be greater with Greek autonomy. The new British government of Lord Grey, with Lord Palmerston as Foreign Secretary, was more favourable to the Greeks. ${ }^{161}$

On 3 February 1930, at the London Conference, a protocol was signed making Greece independent. Another London protocol (8 April 1830) referred to the 'frightful calamities to humanity', which made the internationalization of the problem inevitable. ${ }^{162}$ Following the assassination of Capodistrias in 1831, Greece became a kingdom under Otto, the son of Ludwig of Bavaria. In 7 May 1832 a treaty was signed by the three powers and Bavaria which fixed the frontier as proposed - between the Gulf of Volos and the Gulf of Arta. Finally, Greek independence and its frontiers were accepted by the Porte in a convention signed in Constantinople (21 July 1832). ${ }^{163}$

\section{Motives for intervention and views of publicists}

As we have seen, one of the official justifications for the three-power intervention concerned humanitarian factors. And had it not been for the humanitarian plight and identification with the Greeks among the educated publics in Britain, Russia and France, none of the three states would have contemplated intervening. As the war dragged on and the Greeks held their own, strategic, balance-of-power and economic concerns came to the fore, above all not to allow any of three powers to gain advantage from the Greek case. The crisis, the gravest until then of the so-called Eastern Question, namely the fate of the Ottoman Empire in decline, could not but be a key concern of the great powers. For Russia it was also a question of preserving its prestige and influence among the Balkan Christians. ${ }^{164}$

Among publicists the pace was set by Wheaton as early as 1836 , who asserted that this intervention was 'more justifiable' than other cases for it rescued 'a whole nation, not merely from religious persecution, but from the cruel alternative of being transported from their native land, or exterminated by their merciless oppressors. ${ }^{165}$ His conclusion is worth stressing: 'The interference of the Christian powers, to put an end to this bloody contest might, therefore, have been safely rested upon this ground alone [i.e. the ground of what he calls "the right of human nature"] without appealing to the interests of commerce and of the repose of Europe, which, as well as the interests of humanity, are alluded to in the treaty'. ${ }^{166}$ Similarly Rougier pointed out that ' $[\mathrm{i}] \mathrm{t}$ is reasons of humanity in the 
widest sense of the word ... and of moral dignity which dictated this intervention of the powers ... in the general interest of Europe and civilisation. But the reasons of humanity were not yet regarded in that epoch as a just cause for intervention, thus the Treaty of London mentions it timidly'. ${ }^{167}$

On the whole, from the 183 os until the 1930 os publicists who were advocates of humanitarian intervention referred approvingly to this intervention (we have identified twenty such publicists) as motivated solely or mainly by humanitarian reasons (this is the majority view) or at least partly by humanitarian reasons (the minority view). ${ }^{168}$ John Stuart Mill also referred approvingly to intervention on behalf of the Greeks on humanitarian grounds (see chapter 5 ).

Surprisingly, in the nineteenth century even some of the jurists opposed to humanitarian intervention condone this one case on humanitarian or moral grounds (at least eight of them). ${ }^{169}$ For instance, Calvo stated (in 1870) that the intervention in favour of Greece was dictated by moral and political considerations of the highest and most respectable order'. ${ }^{170}$ Even more surprising is the view expressed by Senior, one of the earliest opponents of humanitarian intervention, put forward eleven years after the independence of Greece: ${ }^{171}$

The treaty of $1827 \ldots$ was ... the most disinterested interference of sovereigns in behalf $[s i c]$ of a people that has occurred in modern times... The long duration of the contest - the ferocity with which it was carried on by the Turks - the apparent success of Greece against her gigantic enemy until she was crushed by the invasion from Egypt - the fear of having to witness the utter extirpation of a Christian population by Mohametans, that Christian population being the descendants of those to whom the world owes its civilization; - all these were motives which it would have been hard to withstand, even if the interference had been a matter of difficulty or danger.

In Senior's assertion one sees almost all the grounds of the publicists (from the 1830 s until the 1930s) justifying the humanitarian intervention (HI). They are as follows: (1) protracted barbarous war, the culprits being the 'Turks' and Egyptians (claimed by eleven pro-HI publicists and four anti-HI); (2) relative disinterestedness on the part of the three intervening states, the predominant aim being to stop the 'effusion of blood' (claimed by fourteen pro-HI and five anti-HI); (3) the barbarization project and danger of annihilation of the Greeks (claimed by two pro-HI and two anti-HI); (4) 'Turkish' despotism, oppression and religious persecution (claimed by six pro-HI and one anti-HI); and (5) debt of Europe and humankind to the ancestors of the Greeks (claimed by three pro-HI and one anti-HI).

The views of two well known supporters of humanitarian intervention are worth referring to. According to Harcourt: ${ }^{172}$

The Battle of Navarino may have been an 'untoward event,' but it was the natural and almost inevitable consequence of a forcible intervention to prevent the Turkish 
Government from reducing its subjects to submission. The emancipation of Greece, effected by Europe, was a high act of policy above and beyond the domain of law. As an act of policy, it may have been, and probably was, justifiable.

According to Lawrence: ${ }^{173}$

The contest between them [the Greeks] and their Turkish oppressors had gone on for many years, and had been marked throughout by the most horrible barbarities. It seemed as if it would end in the extermination of the whole Greek race. The intervention of the three powers preserved a people to whom civilization owned so much and laid the foundations of a new order in Southeastern Europe, which, with all its defects, is infinitely preferable to the chaos of weltering barbarism that immediately preceded it.

The view of a prominent opponent of humanitarian intervention is also worth mentioning. Thomas Alfred Walker, writing in the 1890 s, criticized intervening on the 'dictates of humanity' as opening 'a wide door to outrage' ${ }^{174}$ but added: ${ }^{175}$

On the other hand, the cause of humanity was undoubtedly really served by that intervention of the Powers which led to the establishment of the modern kingdom of Greece. It was not until after several years of singularly bloody struggle and the enactment of a long series of frightful scenes of horror, when it became evident that the alternative offered to Europe was the independence or the annihilation of the Greeks, that Great Britain, France and Russia agreed to combine their efforts.

After 1945 the jurists supportive of humanitarian intervention also tend to refer to the Greek case as the first such instance. ${ }^{176}$ But those opposed, contrary to before, do not regard it as humanitarian. Ian Brownlie, for instance, argues that the collective intervention in Greece is an example of 'ex post factoism', for ' $\mathrm{t}$ ] he governments of the time did not use a legal justification' for intervening, as no such right existed then. ${ }^{177}$ For others, their reading of the official stance on intervention leads them to the conclusion that humanitarian reasons were nonexistent or secondary. ${ }^{178}$

\section{Concluding remarks}

The Greek case, apart from being regarded as the first case of humanitarian intervention, providing the springboard for the emergence of the new concept, has a bearing on the evolution of international norms and rules of conduct in instances of humanitarian plights in a number of ways.

First is the exceptional overruling of the grundnorms of sovereignty and nonintervention in instances of 'effusion of blood' that shake the moral consciousness of humankind.

Second is the multilateral character of the intervention, in this case an 'alliance of the willing', of three of the five powers. 
Third, in this first case one sees most of the repertoire of international involvement on humanitarian grounds: consultation of the powers, peremptory demands made of the guilty state (to halt barbarities and distinguish between guilty and innocent), formal great power agreements, calls for a cease-fire, mediation attempts, a peace conference, an important battle, a peacekeeping force and, at the end, an all-out war by one of the powers condoned by the rest.

Fourth is the reticence or hostility of the powers on instrumental Realpolitik grounds, and when the need for intervention becomes more evident, a mixture of humanitarian and instrumental motives. Moreover, there is a deliberate attempt to check abuse by including self-denying clauses in the relevant texts.

Fifth, it is a clear manifestation of the civilized-barbarians binary that was to dominate the scene until 1914: the 'civilized Christians' as opposed to the Muslim 'barbarian Other', with the latter prone to committing slaughters and atrocities. The massacres of Muslims were swept under the carpet, as if the Muslim victims of the Christians were less human. ${ }^{179}$

Last but not least is the role played by civil society across Europe and in North America in spurring intervention on humanitarian and other ethical grounds, in this case of members of the elite, politicians, thinkers, writers, poets and artists (including celebrities), which was unprecedented and a sign of things to come.

\section{Notes}

1 J. R. Vincent, Nonintervention and International Order (Princeton: Princeton University Press, 1974), 74 .

2 Ibid., 73, 74, 80; C. Holbraad, The Concert of Europe: A Study in German and British International Theory 1815-1914 (London: Longman, 1970), 22-34; W. G. Grewe, The Epochs of International Law (Berlin: Walter de Gruyter, 2000, translated and revised by M. Byers), 488.

3 Quoted in M. Wight, 'Western Values in International Relations', in H. Butterfield and M. Wight (eds), Diplomatic Investigations: Essays in the Theory of International Politics (London: Allen and Unwin, 1966), 118. For Castlereagh's approach regarding nonintervention, see Vincent, Nonintervention and International Order, 73-83.

4 P. K. Grimsted, The Foreign Ministers of Alexander I: Political Attitudes and the Conduct of Russian Diplomacy, 1801-1825 (Berkeley: University of California Press, 1969), 247-8.

5 H. Temperley, The Foreign Policy of Canning 1822-1827 (London: Frank Cass, 1966) [1925].

6 R. Little, Intervention: External Involvement in Civil Wars (London: Martin Robertson, 1975), 18, 23-4.

7 'Non-intervention is a diplomatic and enigmatic word which means more or less the same thing as intervention'. In Granville Stapleton, Intervention and Non-Intervention or the Foreign Policy of Great Britain from 1790 to 1865 (London: John Murray, 1866), 15. For a slightly different version, with the words métaphysique et politique (metaphysical and political), see Wight, 'Western Values in International Relations', 115.

8 J. W. Garner. 'Recognition of Belligerency', American Journal of International Law, 32:1 (1938), 106-13; R. A. Falk, 'Janus Tormented: The International Law of Internal Law', in 
J. N. Rosenau (ed.), International Aspects of Civil Strife (Princeton: Princeton University Press, 1964), 194-209.

9 Garner, 'Recognition of Belligerency', 111-13.

10 G. Finlay, History of the Greek Revolution (London: William Blackwood and Sons, 1861), vol. I, 20, 119-20; L. S. Stavrianos, The Balkans Since 1453 (London: Hurst, 2000) [1958], $211-12,278$.

11 Stavrianos, The Balkans Since 1453, 269-76; R. Clogg, A Concise History of Greece (Cambridge: Cambridge University Press, 1992), 21-30.

12 T. Gordon, History of the Greek Revolution (Edinburgh: William Blackwood, 1844, 2nd edition) [1832], vol. I, 40-8, 50; Finlay, History of the Greek Revolution, vol. I, 120; T. C. Prousis, Russian Society and the Greek Revolution (DeKalb: Northern Illinois University Press, 1994), 18-23; D. Brewer, The Greek War of Independence: The Struggle for Freedom from Ottoman Oppression and the Birth of the Modern Greek Nation (Woodstock: Overlook Press, 2001), 26-7; B. Jelavich, Russia's Balkan Entanglements 1806-1914 (Cambridge: Cambridge University Press, 1991), 51.

13 P. K. Grimsted, 'Capodistrias and a "New Order" for Restoration Europe: The "Liberal Ideas” of a Russian Foreign Minister', Journal of Modern History, 40:2 (1968), 170-3, 180-5, 190-2; Grimsted, The Foreign Ministers of Alexander I, 226, 229, 233-5, 238; C. M. Woodhouse, Capodistria: The Founder of Greek Independence (London: Oxford University Press, 1973), 149-52, 185-6, 189.

14 Finlay, History of the Greek Revolution, vol. I, 135.

15 'Zapiska Grafa Ioanna Kapodistria o ego sluzhebnoj dejatel'nosti', Geneva, 12/24 December 1826 [Memorandum of Count Ioannis Capodistrias on his official activity], Sbornik Russkogo Istoricheskogo Obshchestvo [Collection of the Russian Historical Society], vol. III (St Petersburg, 1868), 215-20 (henceforth 'Capodistrias Memorandum').

16 Woodhouse, Capodistria, 164-6, 169, 180, 218-30; Finlay, History of the Greek Revolution, vol. I, 135-7; M. S. Anderson, The Eastern Question, 1774-1923: A Study in International Relations (London: Macmillan, 1966), 51-2; Brewer, The Greek War of Independence, 31-5; Prousis, Russian Society and the Greek Revolution, 20-3.

17 C. M. Woodhouse, The Greek War of Independence (London: Hutchinson's University Library, 1952), 45 .

18 Ibid., 45, 54; R. B. Mowat, A History of European Diplomacy, 1815-1914 (London: Edward Arnold, 1922), 32; J. A. R. Marriott, George Canning and His Times: A Political Study (London: John Murray, 1903), 83; H. Nicolson, The Congress of Vienna: A Study in Allied Unity, 1812-1822 (London: Methuen, 1946), 259-63, 270.

19 Woodhouse, The Greek War of Independence, 54.

20 J. A. R. Marriott, The Eastern Question: An Historical Study in European Diplomacy (Oxford: Clarendon Press, 1918), 194.

21 Capodistrias Memorandum, 215-20, 224-6, 228-9, 239-42, 256-7; Woodhouse, Capodistria, 163, 174, 180, 191, 198, 201; D. C. Fleming, John Capodistrias and the Conference of London (1828-1831) (Thessaloniki: Institute for Balkan Studies, 1970), 6.

22 Stavrianos, The Balkans Since 1453, 149-50, 280-1.

23 Quoted in Woodhouse, Capodistria, 252.

24 Marriott, The Eastern Question, 197.

25 Gordon, History of the Greek Revolution, vol. I, 96-124, 132-3; Finlay, History of the Greek Revolution, vol. I, 140-70; W. A. Phillips, The War of Greek Independence (London: Smith, Elder and Co., 1897), 32-43; Prousis, Russian Society and the Greek Revolution, 26-8; Brewer, The Greek War of Independence, 51-61. 
26 Gordon, History of the Greek Revolution, vol. I, 57-8, 77, 86; D. Dakin, The Greek Struggle for Independence, 1821-1833 (London: B. T. Batsford, 1973), 27-8; Anderson, The Eastern Question, 53-4; Clogg, A Concise History of Greece, 33.

27 Woodhouse, Capodistria, 234, 241, 245; Jelavich, Russia's Balkan Entanglements, 53; A. Zorin, "Star of the East": The Holy Alliance and European Mysticism', Kritika: Explorations in Russian and Eurasian History, 4:2 (2003), 338.

28 R. Albrecht-Carrié, A Diplomatic History of Europe Since the Congress of Vienna (London: Methuen, 1958), 40.

29 According to a Prussian mémoire (whose author was the historian Ancillon) the Sultan's despotism was a travesty of government and no duty existed to obey it by the Greeks. See A. von Prokesch-Osten, Istoria tis epanastaseos ton Ellinon kata tou Othomanikou kratous en etei 1821 (Athens: Athinas, 1868 , translated from the German by G. E. Antoniades), vol. I, 155-6, n*. See also H. A. Kissinger, A World Restored (Gloucester: Peter Smith, 1973), 290, 296; C. Webster, The Foreign Policy of Castlereagh 1815-1822 (London: G. Bell and Sons, 1963), 363 .

30 Ibid., 360-1; Marriott, The Eastern Question, 206; G. D. Clayton, Britain and the Eastern Question: Missolonghi to Gallipoli (London: Lion Library, 1971), 45; Nicolson, The Congress of Vienna, 271; C. W. Crawley, The Question of Greek Independence: A Study of British Policy in the Near East, 1821-1933 (New York: Howard Fertig, 1973) [1930], 18-20.

31 Gordon, History of the Greek Revolution, vol. I, 39.

32 H. Erdem, "'Do Not Think of the Greeks as Agricultural Labourers": Ottoman Responses to the Greek War of Independence', in F. Birtek and T. Dragonas (eds), Citizenship and the Nation-State in Greece and Turkey (London: Routledge, 2005), 67-9, 76-7; H. Ş. Ilicak, 'The Revolt of Alexandros Ipsilantis and the Fate of the Fanariots in Ottoman Documents', in P. Pizanias (ed.), I Elliniki Epanastasi tou 1821: ena evropaiko gegonos (Athens: Kedros, 2009), 321-5, 328-30; Temperley, The Foreign Policy of Canning, 322-3.

33 Finlay, History of the Greek Revolution, vol. I, 172.

34 Ibid., vol. I, 172, 181-8, 261-3; Phillips, The War of Greek Independence, 48, 55-61, 66-7; W. St Clair, That Greece Might Still Be Free: The Philhellenes in the War of Independence (Cambridge: Open Book, 2008) [1973], 1-2, 7, 12; D. Rodogno, Against Massacre: Humanitarian Intervention in the Ottoman Empire, 1815-1914. The Emergence of a European Concept and International Practice (Princeton: Princeton University Press, 2012), 65-6.

35 Finlay, History of the Greek Revolution, vol. I, 226-8, 38; Gordon, History of the Greek Revolution, vol. I, 185-90; Prokesch-Osten, Istoria, vol. I, 73, 85; Woodhouse, The Greek War of Independence, $\mathbf{5 1 .}$

36 Finlay, History of the Greek Revolution, vol. I, 229-31, 238; Gordon, History of the Greek Revolution, vol. I, 185-8, 196; Prokesch-Osten, Istoria, vol. I, 77; Phillips, The War of Greek Independence, 77-8.

37 Prokesch-Osten, Istoria, vol. I, 85, 88-9.

38 Webster, The Foreign Policy of Castlereagh, 362; Woodhouse, Capodistria, 263-4; Dakin, The Greek Struggle for Independence,142-3, 145; Jelavich, Russia's Balkan Entanglements, 57, 59; V. J. Puryear, France and the Levant: From the Bourbon Restoration to the Peace of Kutiah (Hamden: Archon Books, 1968), 28-9.

39 Prousis, Russian Society and the Greek Revolution, 26; Prokesch-Osten, Istoria, vol. I, 74-5, 81-2, 226, 245; Marriott, The Eastern Question, 206; Woodhouse, Capodistria, 17, 260-3, 269-78; Jelavich, Russia's Balkan Entanglements, 49-50, 53, 58, 64; D. MacKenzie, Imperial Dreams, Harsh Realities: Tsarist Russian Foreign Policy, 1815-1917 (Forth Worth: Harcourt Brace College Publishers, 1994), 41. 
40 Prousis, Russian Society and the Greek Revolution, 26.

41 Ibid., 30-2; Jelavich, Russia's Balkan Entanglements, 62, 64-5; Woodhouse, Capodistria, $260-78$.

42 Webster, The Foreign Policy of Castlereagh, 360-1, 364.

43 Quoted in Capodistrias Memorandum, 269.

44 Ibid., 269-72.

45 Ibid., 285-6; Marriott, The Eastern Question, 205-7; Crawley, The Question of Greek Independence, 17-23; Woodhouse, Capodistria, 290-1; Prousis, Russian Society and the Greek Revolution, 33 .

46 Gordon, History of the Greek Revolution, vol. I, 243-7; Finlay, History of the Greek Revolution, vol. I, 264-70; Phillips, The War of Greek Independence, 56, 60-1; St Clair, That Greece Might Still Be Free, 44-6; Brewer, The Greek War of Independence, 119-23; G. J. Bass, Freedom's Battle: The Origins of Humanitarian Intervention (New York: Vintage Books, 2009), 64-5.

47 Gordon, History of the Greek Revolution, vol. I, 358.

48 Quoted in Rodogno, Against Massacre, 69.

49 Gordon, History of the Greek Revolution, vol. I, 350-60; Finlay, History of the Greek Revolution, vol. I, 306-15; Woodhouse, The Greek War of Independence, 87-8; St Clair, That Greece Might Still Be Free, 78-82; Bass, Freedom's Battle, 67-75; Brewer, The Greek War of Independence, 154-67.

50 Ibid., 167.

51 Quoted in Prokesch-Osten, Istoria, vol. I, 186-7.

52 Ibid., 188-9.

53 Woodhouse, Capodistria, 299.

54 Finlay, History of the Greek Revolution, vol. II, 3-4; St Clair, That Greece Might Still Be Free, 13-91, 119-49, 263-76, 297-304; Woodhouse, The Greek War of Independence, 52-3, 89; C. M. Woodhouse, The Philhellenes (London: Doric, 1977); Marriott, The Eastern Question, 209-10; Mowat, A History of European Diplomacy, 46-7; Clayton, Britain and the Eastern Question, 46-7; Brewer, The Greek War of Independence, 137-53; Bass, Freedom's Battle, 52-5, 57-8, 60-3, 76-110.

55 See references above (note 54). For the stance of the Americans see details in Bass, Freedom's Battle, 88-99.

56 Quoted in St Clair, That Greece Might Still Be Free, 54.

57 Ibid., 13-22, 51-65; Marriott, The Eastern Question, 194, 204-5, 209-10; Albrecht-Carrié, A Diplomatic History of Europe Since the Congress of Vienna, 44.

58 Prousis, Russian Society and the Greek Revolution, xiii-ix, 3, 8-24, 30, 56, 84-158; T. C. Prousis, 'Russian Philorthodox Relief During the Greek War of Independence', University of North Florida, History Faculty Publications, Paper 17 (1985), 31-62 (http:// digitalcommons.unf.edu/ahis_facpub/17); S. Ghervas, 'Le philhellénisme russe: union d' amour ou d' intérêt?', in C. Montandon (ed.), Regards sur le philhellénisme (Geneva: Permanent Mission of Greece to the United Nations, 2008), 33-41.

59 G. L. Ars, Eteristskoe dvizhenie v Rossii. Osvoboditelnaya bor'ba gretseskogo naroda $v$ natsale 19ogo veka i russkogrecheskye svyazy (Moscow: Nauka, 1970), ch. 8; G. L. Ars, 'Aleksandr Ipsilanti i ego vzaimootnosheniya s pravitel'stvom Rossii (novye arkhivnye dannye', in I. S. Dostyan (ed.), Rossiya i Balkany. Iz istorii obshchestvenno-politicheskikh kul'turnykh svyazey XVIIIv-1878 (Moscow: no publisher stated, 1995), 208-40; O. Orlik, Dekabritsy I evropeiskoe osvoboditel'noe dvizhenie (Moscow: Mysl', 1975), 114-18, 124; V. E. Syroechkovskii, 'Balkanskaya problema v politicheskikh planakh dekabristov', in 
V. E. Syroechkovskii, Iz Istorii dvizheniya dekabristov (Moscow: no publisher stated, 1969), http://decemb.hobby.ru/index.shtml?article/bp, 216-303.

60 A. Dialla, 'Entangled Histories: Russian Decembrists and Greek Revolutionaries in the 1820s', in A. Dialla and N. Maroniti (eds), State, Economy, Society (19th-2oth Centuries): Essays in Honor of Emeritus Professor George B. Dertilis (Athens: Metaixmio, 2013), 87-105.

61 Temperley, The Foreign Policy of Canning, 329.

62 W. Hinde, George Canning (London: Collins, 1973), 384.

63 Ibid., 384; Temperley, The Foreign Policy of Canning, 329.

64 Ibid., 329.

65 Hinde, George Canning, 384-5; Marriott, George Canning and His Times, 118; Nicolson, The Congress of Vienna, 274-5; Clayton, Britain and the Eastern Question, 46.

66 For the possibility of such an alliance see Dakin, The Greek Struggle for Independence, 177; Puryear, France and the Levant, 21-2.

67 Marriott, George Canning and His Times, 118; Clayton, Britain and the Eastern Question, 47; Dakin, The Greek Struggle for Independence, 152; Bass, Freedom's Battle, 113-16; J. Bew, "From Empire to Competitor": Castlereagh, Canning and the Issue of International Intervention in the Wake of the Napoleonic Wars', in B. Simms and D. J. B. Trim (eds), Humanitarian Intervention: A History (Cambridge: Cambridge University Press, 2011), $131-2$.

68 Marriott, The Eastern Question, 209; Temperley, The Foreign Policy of Canning, 326-7; Anderson, The Eastern Question, 58; Clayton, Britain and the Eastern Question, 46; Brewer, The Greek War of Independence, 251.

69 Crawley, The Question of Greek Independence, 27.

70 Quoted in Hinde, George Canning, 385.

71 Marriott, The Eastern Question, 210.

72 Prokesch-Osten, Istoria, vol. I, 353, 368-77; Temperley, The Foreign Policy of Canning, 330-6; Crawley, The Question of Greek Independence, 32, 36-41; Jelavich, Russia's Balkan Entanglements, 69-71; Brewer, The Greek War of Independence, 249-50, 252-3.

73 Finlay, History of the Greek Revolution, vol. II, 165-7; Dakin, The Greek Struggle for Independence, 153-5; Woodhouse, The Greek War of Independence, 105.

74 Bass, Freedom's Battle, 102.

75 Ibid., 106.

76 Blanquière (the driving force in the London Greek Committee) had with the talisman argument convinced Byron to leave Genoa and join the Greeks. See St Clair, That Greece Might Still Be Free, 150-2; Brewer, The Greek War of Independence, 196-8.

77 C. M. Woodhouse, The Battle of Navarino (London: Hodder and Stoughton, 1965), 19.

78 Finlay, History of the Greek Revolution, vol. II, 24-8; Phillips, The War of Greek Independence, 145; St Clair, That Greece Might Still Be Free, 150-4, 166-84; Bass, Freedom's Battle, 109-10.

79 Brewer, The Greek War of Independence, 238, 241.

80 Gordon, History of the Greek Revolution, vol. II, 54, 62-82; Finlay, History of the Greek Revolution, vol. II, 113-14, 128; St Clair, That Greece Might Still Be Free, 233-7.

81 Anderson, The Eastern Question, 57.

82 Quoted in Crawley, The Question of Greek Independence, 46-7.

83 Dakin, The Greek Struggle for Independence, 161-5, 175.

84 Stratford, unlike Strangford (who was send to St Petersburg), was a philhellene. As he put it at the time: 'as a matter of humanity, I wish with all my soul that the Greeks were put in possession of their whole patrimony, and that the Sultan were driven bag and 
baggage into the heart of Asia'. Quoted in Crawley, The Question of Greek Independence, 48 n.14.

85 Temperley, The Foreign Policy of Canning, 341-4; Dakin, The Greek Struggle for Independence, $175-7$.

86 Dakin, The Greek Struggle for Independence, 176; Bass, Freedom's Battle, 123-4.

87 Quoted in Temperley, The Foreign Policy of Canning, 349.

88 Ibid., 353.

89 Stapleton, Intervention and Non-Intervention or the Foreign Policy of Great Britain, 32.

90 Quoted in Marriott, The Eastern Question, 214.

91 Quoted in Woodhouse, The Battle of Navarino, 36.

92 Quoted ibid., 36.

93 Crawley, The Question of Greek Independence, 56; Woodhouse, The Battle of Navarino, 37.

94 Prokesch-Osten, Istoria, vol. II, 17-18, 82; Crawley, The Question of Greek Independence, 56.

95 Quoted in Marriott, The Eastern Question, 214.

96 Grimsted, The Foreign Ministers of Alexander I, 284-5.

97 MacKenzie, Imperial Dreams, Harsh Realities, 44; Prousis, Russian Society and the Greek Revolution, 53 .

98 Clayton, Britain and the Eastern Question, 49; Marriott, The Eastern Question, 212; Crawley, The Question of Greek Independence, 52-3.

99 Temperley, The Foreign Policy of Canning, 352-3; Clayton, Britain and the Eastern Question, 49-50; Crawley, The Question of Greek Independence, 54-5.

100 Temperley, The Foreign Policy of Canning, 353-5; Crawley, The Question of Greek Independence, 58-9; Marriott, The Eastern Question, 214; Mowat, A History of European Diplomacy, 48; Clayton, Britain and the Eastern Question, 50.

101 Crawley, The Question of Greek Independence, 59-61; Marriott, The Eastern Question, 215; Temperley, The Foreign Policy of Canning, 390-92; Anderson, The Eastern Question, 64-5.

102 Bass, Freedom's Battle, 127-8; Brewer, The Greek War of Independence, 286-7; St Clair, That Greece Might Still Be Free, 243.

103 Quoted in St Clair, That Greece Might Still Be Free, 270.

104 Ibid., 269-71, 273-6; D. Barau, 'Le movement philhellène en France à travers les listes de souscription du comité grec de Paris', in E. Chrysos and C. Farnaud (eds), La France et la Grèce au XIX siècle. Actes du Colloque franco-hellénique (Athens: Fondation du Parlement Hellénique pour le Parlementarisme et la Démocratie, 2011), 277-89; C. Farnaud, '1821: Que dissent les consuls français?', in Chrysos and Farnaud (eds), La France et la Grèce au XIX siècle, 21-2; Brewer, The Greek War of Independence, 316-17.

105 Woodhouse, The Battle of Navarino, 25-7; Crawley, The Question of Greek Independence, 71.

106 Prokesch-Osten, Istoria, vol. II, 125.

107 Ibid., vol. II, 168.

108 Marriott, The Eastern Question, 217.

109 Hinde, George Canning, 457.

110 Crawley, The Question of Greek Independence, 65; Anderson, The Eastern Question, 65.

111 Marriott, The Eastern Question, 218; Temperley, The Foreign Policy of Canning, 394-6; Crawley, The Question of Greek Independence, 64, 72 .

112 Crawley, The Question of Greek Independence, 70; Dakin, The Greek Struggle for Independence, 182.

113 Quoted in Marriott, The Eastern Question, 218. 
114 Temperley, The Foreign Policy of Canning, 397-400; Dakin, The Greek Struggle for Independence, 182-3; Crawley, The Question of Greek Independence, 75-6; Jelavich, Russia's Balkan Entanglements, 81-2; Hinde, George Canning, 456-7.

115 Treaty of London, in Modern History Sourcebook, http://www.fordham.edu/Halsall/ mod/1827gktreaty.asp.

116 J.-P. L. Fonteyne, 'The Customary International Law Doctrine of Humanitarian Intervention: Its Current Validity Under the U.N. Charter', California Western International Law Journal, 4 (1973-74), 208.

117 Treaty of London.

118 Quoted in Woodhouse, The Greek War of Independence, 122.

119 Quoted in ibid., 123.

120 Marriot, The Eastern Question, 219.

121 Woodhouse, The Greek War of Independence, 123.

122 Crawley, The Question of Greek Independence, 77.

123 Ibid., 77.

124 Woodhouse, The Greek War of Independence, 121.

125 Anderson, The Eastern Question, 67.

126 Finlay, History of the Greek Revolution, vol. II, 138-9; Dakin, The Greek Struggle for Independence, 220-1; Woodhouse, Capodistria, 322-5; St Clair, That Greece Might Still Be Free, 325-7.

127 Woodhouse, The Battle of Navarino, 6o; Prokesch-Osten, Istoria, vol. II, 172.

128 Ibid., vol. II, 183-4.

129 Woodhouse, The Battle of Navarino, 60.

130 Hinde, George Canning, 457; Anderson, The Eastern Question, 67.

131 Quoted in Marriott, George Canning and His Times, 130.

132 Woodhouse, The Battle of Navarino, 77-80.

133 Ibid., 95, 105.

134 Ibid., 106.

135 Finlay, History of the Greek Revolution, vol. II, 181-3; Woodhouse, The Battle of Navarino, 29, 120-40.

136 Bass, Freedom's Battle, 137-51.

137 Rodogno, Against Massacre, 88.

138 Ibid., 88.

139 Albrecht-Carrié, A Diplomatic History of Europe Since the Congress of Vienna, 39.

140 Anderson, The Eastern Question, 67.

141 Crawley, The Question of Greek Independence, 97; Finlay, History of the Greek Revolution, vol. II, 183-4.

142 Marriott, The Eastern Question, 221; Crawley, The Question of Greek Independence, 92.

143 Clayton, Britain and the Eastern Question, 54; Woodhouse, The Battle of Navarino, 162.

144 Ibid., 154-60.

145 Ibid., 163.

146 Ibid., 163.

147 Prokesch-Osten, Istoria, vol. II, 199-205, 211-13; Crawley, The Question of Greek Independence, 92.

148 Prokesch-Osten, Istoria, vol. II, 208-9.

149 Ibid., vol. II, 215-17.

150 Fleming, John Capodistrias and the Conference of London, 14.

151 Clayton, Britain and the Eastern Question, 54. 
152 Marriott, The Eastern Question, 221.

153 Mowat, A History of European Diplomacy, 51.

154 V. Sheremet, 'The Greek Revolution of 1821: A New Look at Old Problems', Modern Greek Studies Yearbook, 8 (1992), 44-53.

155 Crawley, The Question of Greek Independence, 104.

156 Quoted in ibid., 104-5.

157 Fleming, John Capodistrias and the Conference of London, 49-56; Puryear, France and the Levant, 52, 54-7.

158 Crawley, The Question of Greek Independence, 143-8, 153-5; Woodhouse, The Greek War of Independence, 130-2; Fleming, John Capodistrias and the Conference of London, 58-63; Dakin, The Greek Struggle for Independence, 259-61.

159 Quoted in Anderson, The Eastern Question, 71.

160 Ibid., 71.

161 Crawley, The Question of Greek Independence, 119-20, 171; Anderson, The Eastern Question, 274-5; Woodhouse, The Greek War of Independence, 139-41; Jelavich, Russia's Balkan Entanglements, 85-6.

162 Rodogno, Against Massacre, 88.

163 Mowat, A History of European Diplomacy, 52-3; Jelavich, Russia's Balkan Entanglements, 87.

164 Marriott, George Canning and His Times, 118; Crawley, The Question of Greek Independence, 77; Clayton, Britain and the Eastern Question, 47; Dakin, The Greek Struggle for Independence, 152; Prousis, Russian Society and the Greek Revolution, 53; Bass, Freedom's Battle, 113-16; Bew, 'From Empire to Competitor', 131-2; M. Finnemore, 'Constructing Norms of Humanitarian Intervention', in P. J. Katzenstein (ed.), The Culture of National Security (New York: Columbia University Press, 1996), 163.

$165 \mathrm{H}$. Wheaton, Elements of International Law (Boston: Little, Brown, 1866, 8th edition, edited by R. H. Dana) [1836], 115 .

166 Ibid., 115-16.

167 A. Rougier, 'La théorie de l'intervention d'humanité', Revue générale de droit international public, 17 (1910), 473.

168 Apart from Wheaton and Rougier, see the following: A. G. Heffter, Le droit international de l'Europe (Berlin: H. W. Muller; Paris: A. Cotillon et Cie, 1883, 4th French edition translated from the German by J. Bergson) [1844], 114; R. Phillimore, Commentaries upon International Law (London: Butterworth, 1879, 3rd edition) [1854], vol. I, 569; T. D. Woolsey, Introduction to the Study of International Law (London: Sampson Low, Marston, Searle and Rivington, 1879, 5th edition revised and enlarged) [1860], 60; M. Bernard, On the Principle of Non-Intervention. A Lecture Delivered in the Hall of All Souls College, December MDCCCLX (Oxford: J. H. and J. Parker, 1860), 22; W. V. Harcourt, as Historicus, in Letters by Historicus on Some Questions of International Law. Reprinted from 'The Times' with Considerable Additions (London: Macmillan, 1863), 6; E. S. Creasy, First Platform of International Law (London: John van Voorst, 1876), 300; F. Martens, 'Étude historique sur la politique Russe dans la question d'Orient', Revue du droit international et de législation comparée, 9 (1877), 55, 58; Bluntschli, 'Le Congrès de Berlin et sa portée au point de vue du droit international', Premier Article, Revue de droit international et de législation comparée, 11 (1879), 5; S. Amos, Lectures on International Law (London: Stevens and Sons, 1874), 40; G. Rolin-Jaequemyns, 'Chronique du droit international', Revue de droit international et de législation comparée, vol. 10 (1878), 19; T.J. Lawrence, The Principles of International Law (Boston: D. C. Heath, 1905, 3rd edition, revised) [1895], 132; W. E. 
Lingelbach, 'The Doctrine and Practice of Intervention in Europe', Annals of the Academy of Political and Social Science, 16 (July 1900), 19-20; L. Oppenheim, International Law: A Treatise (London: Longmans, Greene, 5th edition, edited by H. Lauterpacht, 1937) [1905], vol. I, 255, para. 137; J. B. Moore, A Digest of International Law (Washington, DC: Government Printing Office,, 1906), vol. VI, 5; A. S. Hershey, 'The Calvo and Drago Doctrines', American Journal of International Law, 1:1 (1907), 42; E. C. Stowell, Intervention in International Law (Washington, DC: John Byrne, 1921), 126-7; A. Mandelstam, 'La protection des minorités', Recueil des cours de l'Académie de droit international, 1 (1923), 374-5; S. Séfériadès, 'Principes généraux du droit international de la paix', Recueil des cours de l'Académie de droit international, 34 (1930), 389.

169 J. Kent, Kent's Commentary on International Law (Cambridge: Deighton, Bell, 1878, 2nd edition, edited by J. T. Abdy), 47-50; N. W. Senior, 'Art.I-1. Histoire du Progrès du Droit des Gens depuis la Paix de Westphalies jusqu'au Congrès de Vienne. Par Henry Wheaton', Edinburgh Review, 77:156 (1843), 345; H. W. Halleck, Halleck's International Law or Rules Regulating the Intercourse of States in Peace and War (London: Kegan Paul, Trench, Trubner, 1893, 3rd edition, edited by S. Baker) [1861], vol. I., 511; C. Calvo, Le droit internationale: théorie et pratique (Paris: Guillaumin et Cie, G. Pedone-Lauriel, 1880, 3rd edition) [1870], 264, para. 167; H. Strauch, Zur Interventionslehere: eine völkerrechtliche Studie (Heidelberg, 1879), 277; F. Despagnet, Cours de droit international public (Paris: L. Larose, 1894), 198; T. A. Walker, A Manual of Public International Law (Cambridge: Cambridge University Press, 1895), 22-3; G. G. Wilson, International Law (New York: Silver, Burdett, 1922, 8th edition) [1901], 91-2.

170 Calvo, Le droit international, 264, para. 167.

171 Senior, 'Art. I-1', 345.

172 Harcourt, Letters by Historicus on Some Questions of International Law, 6.

173 Lawrence, The Principles of International Law, 132.

174 Walker, A Manual of Public International Law, 22.

175 Ibid., 22-3.

176 C. G. Fenwick, 'Intervention: Individual and Collective', American Journal of International Law, 39: 4 (1945), 650; M. Ganji, International Protection of Human Rights (Geneva: University of Geneva, 1962), 22-4; W. M. Reisman with M. McDougal, 'Humanitarian Intervention to Protect the Ibos', in R. B. Lillich (ed.), Humanitarian Intervention and the United Nations (Charlottesville: University Press of Virginia, 1973), 179-80; R. Lillich, 'Humanitarian Intervention: A Reply to Ian Brownlie and a Plea for Constructive Alternatives', in J. N. Moore (ed.), Law and Civil War in the Modern World (Baltimore: Johns Hopkins University Press, 1974), 233; Fonteyne, 'The Customary International Law Doctrine of Humanitarian Intervention', 207-8; M. J. Bazyler, 'Reexamining the Doctrine of Humanitarian Intervention in Light of the Atrocities in Kampuchea and Ethiopia', Stanford Journal of International Law, 23 (1987), 582-3; B. M. Benjamin, 'Unilateral Humanitarian Intervention: Legalizing the Use of Force to Prevent Human Rights Atrocities', Fordham International Law Journal, 16 (1992-93), 128-9; F. K. Abiew, The Evolution of the Doctrine and Practice of Humanitarian Intervention (The Hague: Kluwer Law International, 1999), 48-9.

177 I. Brownlie, 'Humanitarian Intervention', in Moore (ed.), Law and Civil War in the Modern World, 220-1.

178 T. M. Franck and N. S. Rodley, 'After Bangladesh: The Law of Humanitarian Intervention by Military Force', American Journal of International Law, 67:2 (1973), 280; S. Chesterman, Just War or Just Peace? Humanitarian Intervention and International Law (Oxford: Oxford 
University Press, 2001), 29, 32. This is also the view of Charles de Visscher, a supporter of humanitarian intervention. See C. de Visscher, Théories et réalités en droit international public (Paris: Editions A. P. Pedone, 1960, 3rd edition), 159.

179 For this aspect see Finnemore, 'Constructing Norms of Humanitarian Intervention', 163. 